\title{
The Ottawa Field-Naturalists' Club Awards for 2011, Presented April 2012
}

\author{
Ken Allison, Irwin Brodo, Julia Cipriani, Christine Hanrahan, and Eleanor Zurbrigg
}

At the Club's Annual Soiree, held on 21 April 2012, at St. Basil's Church in Ottawa, awards were once again given to members who distinguished themselves by accomplishments in the field of natural history and conservation, or by extraordinary activity within the Club. The following five citations for those who received an award were read to the members and guests assembled for the event.

\section{Anne Hanes Natural History Award: Colin Freebury}

The Anne Hanes Natural History Award recognizes outstanding contributions of an amateur naturalist to our understanding and knowledge of the natural history of the National Capital Region. This year, the worthy recipient is Colin Freebury.

Colin is known to many Club members because of his outstanding photographic skills. In fact, he was practicing those skills on a lichen-hunting field trip a few years ago and became fascinated with the lichens themselves. Anyone who knows Colin wouldn't be at all surprised at this, because Colin has a passion for knowledge coupled with a keen intellect. Once started on his journey to learn more about lichens, there was no looking back. Early on, he decided that he would explore Gatineau Park for its lichens, to contribute whatever he could to what we already knew about the flora. Armed with a collecting permit, knife, hammer, chisel and hand lens, he began to sample the lichens he found throughout the park, photographing many, thereby creating an image library that can be (and has been) used in lectures about the lichens of the park. Each trip brought new discoveries and new names for the list of Gatineau Park lichens. With patience and a keen eye, he found many rarities, a few of them new to the Ottawa Region as a whole. He created an Excel file with information on all the lichens he collected and the ones already deposited in the lichen herbarium at the Canadian Museum of Nature. Each new record was carefully documented. When the list reached 300 and kept on growing (it is now at 324), he thought it was time to share the information, especially since he knew that a new checklist of Quebec lichens was being finalized. The result was an excellent article in Trail \& Landscape (April - June 2011) on the Lichens of Gatineau Park based on a

\section{George McGee Service Award: Ann Prescott}

The OFNC George McGee Service Award is given in recognition of a member who has contributed significantly to the smooth running of the Club over several years.

Ann Prescott has been a member of the Club since 1996, prompted to join by her cousin Dave Moore who was Club president at the time, and by her interest in careful study of herbarium specimens, new field work and the literature. Colin now regularly attends the annual Gatineau Park research seminars run by the NCC to give updates of his findings.

Although the publication of the Gatineau Park lichens is the main reason for the award, it is pertinent to mention other lichenological activities occupying Colin's time. He volunteers at the Canadian Museum of Nature Research and Collections Division, mounting lichen specimens, entering label data into the data processing program, preparing exchanges and loans, and helping out retired lichenologist, Irwin Brodo, in countless other ways. Colin's superb skill in communicating to the public (in both official languages) has not gone unnoticed by the Museum, and they have enlisted his help at Museum "Open Houses" and "Meet the Scientist" events.

Colin has recently deepened and broadened his interest in lichen research. A few summers ago, he travelled to Maine to take a course on crustose lichen identification at Eagle Hill taught by Irwin Brodo. He and Dr. Brodo are now collaborating on a study of the frosted rosette lichen, Physcia aipolia, and its newly discovered sister species, Physcia alnophila, and the manuscript should be submitted soon. His main lichenological project, however, is outside the Ottawa Region. Colin has been visiting and collecting lichens in Grasslands National Park in Saskatchewan for several years, and he is well on his way towards the completion of this mammoth treatment. It seems that Gatineau Park was just the beginning.

All these activities, interests and accomplishments make Colin Freebury a fitting recipient of the Anne Hanes Award for 2011.

birding. In 2004 Ann joined the Education and Publicity Committee and got involved in a range of activities to support the Club's publicity efforts.

Ann has been the welcoming face behind the sales table at the Club's monthly meetings since 2004. She has tirelessly transported the promotional materials, set up the display of pamphlets, $t$-shirts, publications, 
including copies of $\mathrm{CFN}$, and greeting cards before members arrive at 7:00 p.m. and taken it all down at $7: 30$ for the start of the meeting.

In June 2011, she set up the sales table for the first time at the Club's Annual Native Plant Sale at the Fletcher Wildlife Garden. She managed a brisk trade, selling Club T-shirts and several copies of Dan Brunton's Nature and Natural Areas in Canada's Capital, earning over $\$ 200$.

For the past several years Ann has been an anchor at the entrance table for the Club's Annual Soirée, sharing responsibility for selling and taking tickets and managing in-coming traffic.

She has played an important role in the Education and Publicity Committee's drive to increase member- ships. She has set up and staffed the OFNC display at Mud Lake, at Eco-fairs at the RA Centre and the Rideau Trail and at the Wildlife Festival at Billings Bridge, among other places.

Ann participated in the Club's promotional efforts in a number of government departments, including Agriculture Canada, NRCan and Telesat Canada. This involved setting up the Club's display, welcoming the public and answering questions regarding the Club.

She took over the task of ensuring that the Club's pamphlets were on display at the bulletin boards at Stoney Swamp and Jack Pine Trails.

It is for her quiet, behind the scenes generosity of time and energy that we wish to honour Ann with the George McGee Service Award for 2011.

\section{Conservation Award - Member: Dr. Theodore Mosquin}

The Conservation Award for a member is given in recognition of an outstanding contribution by a member in the cause of natural history conservation in the Ottawa Valley, with particular emphasis on activities within the Ottawa District.

Ted Mosquin has been involved with many conservation issues and projects in the Ottawa Valley over many years. The OFNC would like to particularly recognize his role as a guardian and advisor with relation to the Purdon Fen Conservation Area in Lanark County. Ted prepared a long-term management plan for the fen and then served for many years as an interpreter and advisor as well as leading fundraising efforts to pay for interpretive signage and to develop the area for public uses. In recognition of Ted's key role in the ongoing development of the Purdon Fen Conservation Area, the "Ted Mosquin Highland Trail" in the Conservation Area was named in his honour. In 2007, Ted received the Conservation Pioneer Award from the Latornell Conservation Foundation on the recommendation of the Mississippi Valley Conservation Authority for his role in the long term protection of the Showy Lady'sSlipper colony in the fen. Thousands of people visit this site each year and learn about the ecology of orchids and the conservation of wetlands.

In 2002 Ted established the Mississippi-Madawaska Land Trust Conservancy and served as its first president until 2010. This trust enabled private citizens to protect land in its natural state through both agreements and purchase. Almost 2000 acres have already been protected, including some old growth forest areas.

Since 2001 he has been a board member for the Mississippi Conservation Foundation in Lanark, Ontario.

Ted has also served on the Lanark Highlands Environmental Advisory Committee since 2009. This committee was established by the Lanark Highlands Municipal Council to offer advice to the elected members of Council.

In addition to the local involvements for which he is being recognized this year, Ted has been involved in a vast number of national and even international conservation projects and natural history organizations for over 30 years.

For his many years of involvement in conservation issues in the Ottawa valley, the OFNC is pleased to present to Ted Mosquin with the Conservation Award for a Member for 2011.

\section{Mary Stuart Education Award: Dr. Fred Schueler and Aleta Karstad}

The Mary Stuart Education Award is given in recognition of outstanding achievements in the field of natural history education in the Ottawa Region.

Fred Schueler and Aleta Karstad are a talented biologist-artist team well-known in Eastern Ontario for their decades of work researching and documenting natural history observations, through a combination of science and art. The Ottawa Field-Naturalists Club (OFNC) is recognizing two of their projects which relate to natural history education - the popular mudpuppy nights, and the NatureList. Through both of these activities, many people have had their interest in nature either started or strengthened.
Since 1998 Fred and Aleta have offered "Mudpuppy Night in Oxford Mills" to interested observers, leading them on a nocturnal outing at the dam on Kemptville Creek at Oxford Mills. The outing is kid-friendly, and has become a regular annual outing for the OFNC and the Macoun Field Club. Most Friday nights throughout the winter, Fred and Aleta - joined by a group of hardy observers - can be seen in hip waders with flashlights searching the waters for mudpuppies (Necturus maculosus). When spotted, a mudpuppy is dipnetted, admired, photographed, and natural history notes recorded. Through Mudpuppy Nights, the Schuelers have given many youngsters (and even adults) their first 
"hands-on" experience with wildlife - including teaching them the correct way to hold a mudpuppy in their hands (a very special experience) - and demonstrating to them how much they can learn about biology and conservation through this experience.

Another project that Fred and Aleta have initiated is the Eastern Ontario Natural History e-mail listserve, also known as the NatureList. The NatureList began in 1999 as an e-mail listserve, but since September 2008 has been hosted as a Google group. The listserve provides a lively forum for the sharing of nature observations throughout eastern Ontario with a view to getting them on the public record. As well, list members can help one another with species identification and nature interpretation, and discuss issues of interest. Some recent topics on the NatureList have included a discussion about snapping turtles (they are a species at risk yet hunting is allowed); a note posted from another listserve on the types of fruit and the sequence of their consumption by robins; snow type data from snowpack fields; and posting of first spring sightings of various flora and fauna (first red-winged blackbirds, first return-

\section{Member of the Year Award: Barry Cottam}

The OFNC's Member of the Year award recognizes the member judged to have contributed the most to the club in the previous year. Barry Cottam is this year's Member of the Year for his dedicated work as a volunteer at the Fletcher Wildlife Garden (FWG).

Barry became a volunteer at the FWG in 2010 and very quickly discovered the invasive alien plant, dogstrangling vine (DSV for short) (Cynanchum rossicum). It was, he has said, hate at first sight. He was so appalled at how widespread the plant was, that he decided then and there he must help do something about it. Recognizing that many volunteers had previously tackled DSV, he reckoned that a different, more consistent approach was needed. He spent the winter familiarizing himself with the species, reading everything he could find, and talking to others who had first-hand experience with it. Barry's idea was to form an invasive species group that would regularly tackle all invasive plants at the garden, but with a strong emphasis on DSV, especially in the first few years. Thus, The Invasive Species Group (TISG) was born.

In early 2011, Barry gathered together a group of dedicated volunteers, who met every Tuesday morning, spring through fall, to tackle invasive plant species, in particular, DSV. With Barry's input and advice, one of the volunteers set up a blog charting the weekly progress in text and photos. Barry was also responsible for four DSV work bees that averaged 20 people on each occasion. Not content with working only on the regular Tuesday morning, or with the work bees, Barry often ing Canada geese, and so on), which often leads to further discussion by various members of the listserve on related topics. Natural history observations are linked to Fred and Aleta's natural history database which contains some 100,000 records and is growing. Through the interchange of observations, facts and interpretations that occurs on NatureList, the level of knowledge of natural history is raised for a host of amateurs. The listserve is quite lively!

In 2004, Fred and Aleta launched the NatureJournal, an archival journal system that facilitates the recording and preservation of everyone's nature observations.

Over the years Fred and Aleta have also given occasional workshops for OFNC. They have also published a number of illustrated books covering aspects of natural history and conservation.

For their many years of exceptional service raising awareness of natural history conservation in the Ottawa area, the OFNC is pleased to present Fred Schueler and Aleta Karstad with the Mary Stuart Education Award for 2011.

put in long hours at other times too. But apart from the sheer physical labour involved in this very hands-on project, Barry had to coordinate the volunteers. In addition to contacting them if there was a change in plans, and being available for questions and advice, he had to make sure they knew which areas to tackle each week and had the right equipment for the work.

Knowing that control was the key word in this battle against DSV, Barry's main objective was to remove as many seed pods as possible from active production. Two hundred and twenty-five industrial sized bags and innumerable piles of DSV were removed from large sections of the garden. Regular visitors to the FWG commented on the difference. However, Barry knows that one years's work is just the beginning, and the DSV will be back, but so will Barry and his volunteers in 2012 and beyond. He has plans to refine the approach to DSV removal, and also has plans for attracting more volunteers. With his unwavering dedication to this important task, he has made a huge difference at FWG.

As if all this was not enough, Barry also joined the FWG Management Committee where he has quickly become an invaluable member. He has taken on numerous tasks, including researching and overseeing the purchase of a new garden shed (not as simple as it sounds); helping to develop plans for better organizing the nursery, and many other tasks both big and small.

For all of these reasons, we believe that Barry is a fitting recipient of the 2011 Member of the Year Award. 